\title{
Changing Population, Landuse and Environment in the Nepal Himalayas
}

\author{
Prem Sagar Chapagain
}

Central Department of Geography, TU, Kirtipur

\begin{abstract}
Mountain environment is a matter of global concern. In the case of Nepal, population size has been ever increasing with rapid growth rate until 2001. With increasing population size and growth rate, major changes appeared in land use pattern, i.e. increasing agricultural land and decreasing forest coverage. This has alarmed the situation especially during 1980s as it was linked with highland deforestation for agricultural land to fulfill the increasing food demand that resulted lowland sedimentation and flooding. However, population growth rate between 2001-2011 has drastically decreased compared to the past decade. At the same time, literacy and environmental awareness increased, alternative means of income and employment opportunities have increased and poverty has decreased. These changes including the policy of forest management have contributed positively in forest coverage. It has also succeeded to break the previous environmental orthodoxy, population growth- food demand-deforestation/degradation nexus, in the Nepal Himalayas.
\end{abstract}

Key words:Environment, population, deforestation, environmental orthodoxy, livelihood.

\section{INTRODUCTION}

Population of Nepal Himalayas has been constantly increasing since 1941 to present. With increases in population size a rapid changes has appeared in land use (and land cover) pattern in the same period that has resulted substantial loss of forest area and increases in agricultural land. This scenario of environmental change attracted the concern of scholars especially after the UN concern on desertification in 1951 (Gurung, 1981). Since then, there have been several studies about the existing scenario of mountain degradation and the reasons behind it. These studies, in brief, can be grouped into two categories. The studies before mid 1990s claimed the high population growth and ill-farming practices as the major causes of Himalayan degradation. However, studies after 1990s seriously questioned the conclusion of earlier studies about the reasons of the Himalayan degradation and concluded that the earlier claims were inaccurate because such claims accepted 'truth about cause and effect relationship' without detailed examination of the reality about nature and scale of degradation. Based on the changing population and land use and land cover data from 1950, it has tried to examine the population-environment relationship and its interpretation over the time.

Email:ps.chapagain@gmail.com 


\section{METHOD}

This paper is based on the secondary data and literature. The main sources of data are population size and growth rate and changing forest coverage published by Central Bureau of Statistics,Department of Forest, and other concern organizations. The changing land use and land cover data are collected from various study reports by National Planning Commission of Nepal and other organizations. Finally, a critical assessment has been done aiming to frame the earlier explanation of mountain degradation and its counter arguments and the reasons.

\section{RESULT AND DISCUSSION}

the growth rate of 1.35 (Table 1).
Changing population size and growth pattern

Both population size and growth rate of Nepal has been rapidly increased from 1952 to 2001 . During the period the growth rate remains above 2 percent. Compared to the total number of 1971 population, 3466856 people were increased in 1981. About the same number increased from 1981 to 1991. From 1991 to 2001 , it was increased by 4660326 . However, both population size and growth rate have followed a different scenario in 2011. The total number of increased population from 2001 to 2011 remains lower than the previous decade's change and only 3343081 people have been added (without the absent population) having

Table 1: Population size and growth rate of Nepal (1952/54-2001)

\begin{tabular}{|l|l|l|l|l|l|l|l|}
\hline \multicolumn{1}{|c|}{ Census Year } & \multicolumn{1}{|c|}{$\mathbf{1 9 5 2 / 5 4}$} & \multicolumn{1}{|c|}{$\mathbf{1 9 6 1}$} & \multicolumn{1}{c|}{$\mathbf{1 9 7 1}$} & \multicolumn{1}{c|}{$\mathbf{1 9 8 1}$} & \multicolumn{1}{c|}{$\mathbf{1 9 9 1}$} & \multicolumn{1}{c|}{$\mathbf{2 0 0 1}$} & \multicolumn{1}{c|}{$\mathbf{2 0 1 1}$} \\
\hline Population Size & 8256625 & 9412996 & 11555983 & 15022839 & 18491097 & 23151423 & 26494504 \\
\hline Population Growth Rate & 2.27 & 1.64 & 2.05 & 2.62 & 2.08 & 2.25 & 1.35 \\
\hline
\end{tabular}

Source: CBS, 2012.

In the context of spatial distribution pattern, the three regions i.e.Mountain, Hill and Tarai share $6.73,43.0$ and 50.27 percent respectively in 2011. Compared to 2001, it shows the increasing population size in Tarai.

\section{Changing Land use pattern}

Historical data on land use land cover pattern is very limited. The available statistics is also not easily comparable due to the categorization of land use into different class. Robbe's (1954) report is perhaps the first document reporting landuse types of Nepal followed by NPC's (1974) report on landuse and erosion control. In 1954, forest had covered 34 percent of the total land followed by 18 percent forest land. The NPC's (1974) report provided more land use categories in which forest land covered 34 percent and agriculture land covered 16 percent only. While comparing the data with Robbe's report, both forest and agricultural land area had decreased in 1974. But this is not the situation because pasture and meadows also include in cultivated land and importantly barren land in 1974 covered about 19 percent (Table 2).

Table 2: Land use pattern of Nepal 1954 and 1974

\begin{tabular}{|l|c|c|r|r|}
\hline \multirow{2}{*}{ Land use types } & \multicolumn{2}{|c|}{$1954+$} & \multicolumn{2}{c|}{$1974++$} \\
\cline { 2 - 5 } & $\begin{array}{c}\text { Area } \\
(\mathbf{s q k m})\end{array}$ & $\%$ & $\begin{array}{c}\text { Area } \\
(\mathbf{s q} \mathbf{k m})\end{array}$ & $\%$ \\
\hline Forest land & $45,324.83$ & 34.18 & 50,051 & 34.40 \\
\hline Cultivated land & $23,827.91$ & 17.97 & 23,260 & 16.00 \\
\hline Range land & $17,611.93$ & 13.28 & & \\
\hline Glacier and other & $45,842.82$ & 34.57 & & \\
\hline Pasture and meadows & & & 18,530 & 12.73 \\
\hline Barren land & & & 27,283 & 18.75 \\
\hline Snow & & & 21,918 & 15.06 \\
\hline Water & & & 4,151 & 2.85 \\
\hline Settlement and road & & & 321 & 0.21 \\
\hline
\end{tabular}


Total \begin{tabular}{|l|l|l|l|}
\hline 132607,5 & 100 & 145,504 & 100 \\
\hline
\end{tabular}

Source: + Robbe, 1954; + +NPC, 1974

National sample census of agriculture by CBS (2003) provided a more reliable statistics on agricultural land holding numbers and area from 1961 to 2001. Agricultural land area has sharply increased from 1960 to 2001 both in terms of number of holdings and total area. The total number of holdings has increased from
1.54 million in 1961 to 3.36 million in 2001 . More importantly, agricultural land area has increased from 1685 thousand hectares in 1961 to 2654 thousand hectares in 2001. Within 40 years of time from 1961 to 2001, 968 thousand hectares agricultural land area has increased. It has increased by 57 percent with 1.43 percent of annual increasement. The most notable increased has observed from 1971 to 1981 with about 50 percent increment in agricultural land

area. Although agricultural land area has also increased after 1981 but the percentage of change is very slow (Table 3 ).

\section{Table 3: Agriculture land holding number and area 1961-2001}

\begin{tabular}{|l|c|c|c|c|c|}
\hline \multirow{2}{*}{\begin{tabular}{c}
\multirow{2}{*}{ Number of holding and area } \\
\cline { 2 - 6 }
\end{tabular}} & \multicolumn{5}{|c|}{ Year } \\
\cline { 2 - 6 } & $\mathbf{1 9 6 1 / 6 2}$ & $\mathbf{1 9 7 1 / 7 2}$ & $\mathbf{1 9 8 1 / 8 2}$ & $\mathbf{1 9 9 1 / 9 2}$ & $\mathbf{2 0 0 1 / 0 2}$ \\
\hline Number of holdings (million) & 1.54 & 1.721 & 2.194 & 2.7361 & 3.3641 \\
\hline Agricultural land area (million ha) & 1.685 & 1.654 & 2.464 & 2.597 & 2.654 \\
\hline
\end{tabular}

$\%$ change

Source: CBS, 2003.

Forest coverage has undergone a massive change in last 30 years in Nepal. Though there is also data limitation for systematic comparison of forest coverage in Nepal. According to Land Resource Mapping Project (LRMP, 1978/79),

4, Figure 1). forest had foveresg 42.7 percent of the total area of Nepal that was decreased to 35.9 percent in 1984. Forest coverage was increased to 39.6 percent in 1994. However, after 2000, forest coverage has again decreased and remained 38.4 percent in 2000 and 37.6 percent in 2005 . Not only the coverage but also the quality of forest has deteriorated as the coverage of shrub has increased from 4.7 percent in 1978 , to 10.6 percent in 1999 and 12.9 percent in 2005 (Table

\section{Table 4: Percent of land under forest and shrub land, Nepal}

\begin{tabular}{|l|c|c|c|c|c|}
\hline \multicolumn{1}{|c|}{ Types } & LRMP $^{1}(\mathbf{1 9 7 8 / 7 9 )}$ & NRSC $^{\mathbf{2}} \mathbf{( 1 9 8 4 )}$ & NFI $^{\mathbf{3}}(\mathbf{1 9 9 4})$ & $\mathbf{2 0 0 0 +}$ & $\mathbf{2 0 0 5 + +}$ \\
\hline Forest & 38.0 & 35.9 & 29.0 & 26.5 & 24.7 \\
\hline Shrub & 4.7 & - & 10.6 & 11.9 & 12.9 \\
\hline Total & 42.7 & 35.9 & 39.6 & 38.4 & 37.6 \\
\hline
\end{tabular}

1. LRMP: Land Resource Mapping Project, 2.NRSC: National Remote Sensing Center of Nepal

3. NFI: National Forest Inventory, + FAO 2001, ++ FAO 2006

Source: DFRS, 1999; FAO 2001; FAO 2006.

The rate of forest area decreasing has $1.7 \%$ per annum during 1978/79 to 1994. Deforestation remains very high because forest covered about 60 percent of the total area in the decade of 1960 's that has been decreased to $29 \%$ in 
1990’s.

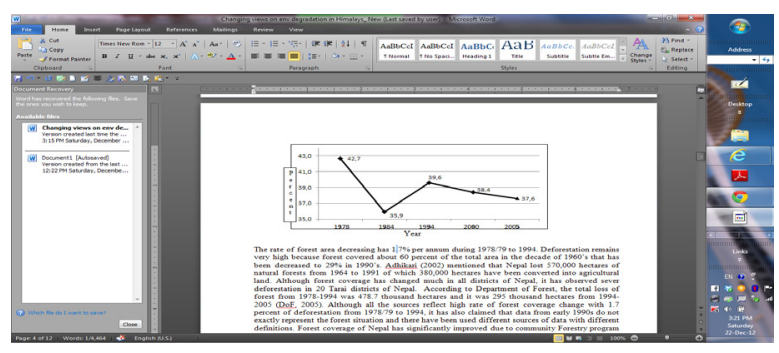

Figure 1: Forest coverage percent, 1978-2005

Adhikari (2002) mentioned that Nepal lost 570,000 hectares of natural forests from 1964 to 1991 of which 380,000 hectares have been convertedinto agricultural land. Although forest coverage has changed much in all districts of Nepal, it has observed sever deforestation in 20 Tarai districts. According to Department of Forest, the total loss of forest from 19781994 was 478.7 thousand hectares and it was 295 thousand hectares from 1994-2005 (DoF, 2005). Although all the sources reflect high rate of forest coverage change with 1.7 percent of deforestation from $1978 / 79$ to 1994 , It has also claimed that data from early 1990s do not exactly represent the forest situation because thesestudies used different sources of data with different definitions. It is important to note that forest coverage of Nepal has significantly improved due to Community Forestry program especially in middle Hill of the country (FRANP, 2010 :http://franepal.org/articles/Data\% 20needs\%20final.pdfaccessed on 14 Dec 2012).

\section{Population-environment-development nexus}

Earlier studies on population - environment relationships had focused on population growth and its effects on environment particularly on increasing trend of deforestation. Populationdeforestation narrative had already started during 1950s (Robbe, 1954; NPC, 1974) and had got its climax with the publication of the Losing Groundin 1976 (Eckholm, 1976).
Eckholm (1976) presented most dramatic picture of the Himalayan degradation by linking population growth as the major cause to upland deforestation for agricultural land that leads landslide and soil erosion in the upland and resulted flooding in the downstream. Because of fulfilling the food and firewood requirement for the increasing number of people, farmers were moved towards the upland forest and even to the marginal areas and finally the Himalayan forest was cleared. The vicious circle of population growth and environmental degradation/deforestation idea was established depending upon neo-Malthusian assumptions concerning the relationship between society and environmental change in the Himalayas.

Later Ives and Messerli (1989) systematically reviewed the earlier generalization of environmental degradation and based on their studies they refuted the earlier explanation of vicious circle of degradation. They concluded that rural people have different methods and techniques of managing different types of lands. In addition, they have also explored the way that rural people manage their firewood for which they collect dry branches of trees from the forest and use agriculture residue, fodder grass residues in the Himalaya. Importantly, they pointed out the extreme weather condition and active bio-physical situation of the Himalaya as the responsible factors for contributing the high amount of soil erosion and sedimentation downstream rather than the farming practices of the rural hill people.

Forest coverage of Nepal had rapidly decreased from 1960 to 1990 mainly because of government policy. Before 1957 forest was the open access resource that was nationalized 1957. Thereafter, it was controlled the access and right to forest. Consequently, it was resulted that people felt no responsibility about its management. Although Nepal government had several forestation programs in each districts, 
no positive contribution was observed in terms of forest coverage and its quality. In addition, Malaria was eradicated in 1960s and thereafter government started resettlement programs in the Tarai. It was motivated migration from Hill and Mountain to the fertile land that contributed in deforestation in Tarai.

Forest has remained one of the major livelihood bases of subsistence farmers of Nepal Himalaya without which livelihood is almost impossible. Gurung (1981) was right who claimed that poverty and lack of other opportunities in rural areaswere the major causes of environmental degradation though he was little listen in that time. For shaping the new degradation discourse, many changes had already taken place by 1990 in the field of development theory and environment policy. Nepal government has also realized the forest management problem and amended its forest policy. The community forestry program was started in late 1990s and thereafteraccess, management and utilization rights of forest were again handed over to the local people especially in hilly region. The result of this policy has found positive and the forest coverage has again increased after 1990. Ives and Messerli (1989) also have conclude that Himalaya is geo-physically very active and climatically very extreme area where physical processes have greater role for soil erosion and land sliding, sedimentation and flooding in the downstream. It does not mean that there is no human impact on mountain environment but the human activities in the Himalayas are not enough to prove the environmental degradation in the claimed scale. Thomson and Warburton (1985) also claimed that the degree of uncertainty regarding the knowledge on environment is high in the Himalayas. Many studies (Blaikie, 1985; Blaikie and Brookfield, 1987; Thompson and Warburton, 1985; Ives \& Messerli, 1989) drew the similar conclusion that the deforestation issue of the Himalayas was based on the limited and short-term observation that deduced the information for the generalization.

Compared to the situation up to 1980, substantial changes have observed in the socio-economic development in the Nepal.For instance literacy rate has increased from 13.9 in 1971, 23.3 in 1981, 39.6 in 1991, 54.1 2001 and 65.9 in 2011. Female literacy rate has also increased from 3.9 in 1971 to 25 in 1991, 57.4 in 2011. Urbanization level has also increased from3.6 in 1961 to 9.4 1981, 14 in 2001 and 17 in 2011(CBS, 1985; CSB, 2012).Dependency to traditional farming has decreased as people get involved in several off-farm income opportunities. About 55 percent households at present receive remittances that contribute 20-25 percent in total GDP (UNDP, 2011). This changes in income has drastically reduced poverty level from 41.8 in 1996 to 30.9 percent in 2004 and 24.8 percent by 2008 (NLSS, 2011). These all aspects positively contributed in Human development that the HDI Index positively changed from 0.291 in 1975 to 0.372 in $1985,0.455$ in 1995 and 0.504 in 2002 (UNDP, 2006).

The degradation of the mountain environment in general and deforestation in particular was not the choice but was the compulsion for the survival. As the changes appeared in income and livelihood opportunities, forest coverage has also increased. But it is crucial that income and better livelihood opportunities are not enough for environment. The governance is also a very important factor. Forest coverage of Nepal has further gone down from 2000 and continued to 2005. It was the time of internal conflict, insecurity andlack of governance in Nepalcaused more deforestation and forest coverage decline.

\section{CONCLUSION}

The environmental problem lies on the hand of the definer. The degraded versions of the environment due to the mal-practices of the local 
people are now critically looked upon and the local farmers are acknowledged for protecting the environment. This sort of receiving narratives without critical assessmentis an environmental orthodoxy that is, to a certain degree, spurred by international concern. The environmental crisis of the Himalayas was also based on the selective perception of the outside observers. Thevicious circle of population growth- upland deforestation- soil erosion- downstream sedimentation came under intense criticism on empirical, theoretical and ideological point of view and in fact does not exist.

Development and environment are closely interrelated. Changes in social and economic aspects of people with more income and employment opportunities contribute positively in environment and resource management. At the meantime, good governance and peace have noticed as a pre requires for sustainable social, economic and environmental development.

\section{REFERENCES}

Adhikari, B. R. 2002. Forest Encroachment: Problems and Solution Measures (in Nepali). Hamro Ban, 103-112pp.

Blaikie, P. 1985. The political economy of soil erosion in developing countries. London: Longman.

Blaikie, P., \& Brookfield, H. 1987. Land degradation and society. London: Methuen

CBS. 1985. Population monograph of Nepal. Kathmandu: Central Bureau of Statistics.

CBS.2003. National sample census of agriculture Nepal (2001/02). Kathmandu: Central Bureau of Statistics.

CBS.1995. Population monograph of Nepal. Kathmandu: Central Bureau of Statistics.

CBS.2012. National population and housing census 2011 (National report). Kathmandu: Central Bureau of Statistics.

DFRS. 1999. Forest Resources of Nepal (19871998). Kathmandu: Department of Forest
Research and Survey, Ministry of Forest and Soil Conservation.

DoF. 2005. Forest Cover Change Analysis of the Terai Districts (1990/91-2000/01). Kathmandu: Department of Forests, Ministry of Forest and Soil Conservation.

Eckholm, E. P. 1976. Losing ground:Environmental stress and world foodprospects. New York: W W Norton.

FAO. 2001. Global Forest Resource Assessment 2000. Rome: Food and Agriculture Organization of the United Nations.

FAO. 2006. Global Forest Resource Assessment 2005. Rome: Food and Agriculture Organization of the United Nations.

Gurung, H. 1981. Ecological changes in Nepal: A native interpretation. An Occasional Paper 1. Kathmandu: New Era.

Ives, J. D., \& Messerli, B. 1989. The himalayan dilemma:Reconciling development and conservation. London/New york: Routledge.

NLSS. 2011. Nepal living standards survey2010/11. Kathmandu: Central Bureau of Statistics.

NPC. 1974. Draft proposal of task forceon land use and erosion control. Kathmandu: National Planning Commission.

Robbe, E. 1954. Report on the government of Nepal on Forestry, ETAP report no 209. Rome.

Thomson, M., \& Warburton, M. (1985). Uncertanity on a Himalayan scale. London: Routledge.

UNCED.1992. Agenda 21: Program of action for sustainable development. United Nations Publications, Chapter 13.

UNDP. 2006. Nepal: Readings in Human Development. Kathmandu: UNDP.

UNDP. 2011. Towards Human Resilience: Sustaining MDG Progress in an Age of Economic Uncertainty (http://www.undp. org/content/dam/undp/library/Poverty $\% 20$ Reduction/Inclusive\%20development/ Towards\%20 Human\%20 Resilience/ Towards_SustainingMDGProgress_Ch4.pdf, accessed on Dec 18, 2012). 